\title{
Secretory Vesicle
}

National Cancer Institute

\section{Source}

National Cancer Institute. Secretory Vesicle. NCI Thesaurus. Code C26063.

A vesicle that transports molecules that are targeted for cellular excretion. 